DOI: https://doi.org/10.32838/2523-4803/70-4-4

UDC 339.9

Poliakova Juliia

Doctor of Economic Sciences, Associate Professor, Lviv University of Trade and Economics

Shaida Oksana

Candidate of Economic Sciences, Associate Professor, Lviv Polytechnic National University

Stepanov Andriy

Senior Lecturer,

Lviv University of Trade and Economics

Полякова Ю.В.

доктор економічних наук, доцент, Львівський торговельно-економічний університет

Шайда O.Є.

кандидат економічних наук, доцент,

Національний університет «Львівська політехніка»

Степанов А.В.

старший викладач,

Львівський торговельно-економічний університет

\title{
PATENTING ACTIVITIES AND TECHNOLOGICAL DEVELOPMENT IN THE GLOBAL ECONOMY
}

The article is devoted to the study of current trends in patenting activities in the context of global economic processes. The priorities and goals of developing a long-term vision of the development of the countries of the world are considered in the context of the formation of the digital economy. The role of legal protection of intellectual property in achieving high rates of patenting is appraised. Comparative data of world patent ratings are given. The existing problems in the domestic patenting of scientific and technical solutions are highlighted. An econometric model of the dependence of the indicator of the number of patent applications filed with the European Patent Organisation on the percentage of human resources engaged in $R \& D$ in the EU has been built. The decisive role of human resources in scientific and technological development and patenting activities is substantiated, which requires a balanced state policy in the direction of improving human capital.

Key words: technologies, technological development, patent, patenting activities, global economy.

Formulation of the problem. The new paradigm of development of the leading economies involves the transition from a post-industrial model to an innovative technological model of management, when competition concerns not only the possession of capital resources and material values, but also the ability to develop and implement effective organisational, commercial and technological innovations.

In the global economy, developed countries focus on priority areas of technological advances aimed at improving social welfare and providing economic development. These are, first and foremost, the areas that provide healthcare, social and environmental solutions, and information and communication technologies that affect all spheres of public life. The rapid growth of competition in the field of patenting the main innovative and technological solutions, the involvement of new entities in these processes bring up to date the compliance of domestic patenting with the global trends and Ukraine's participation in international technological exchange.
Analysis of recent research and publications. Leading domestic and foreign scientists study the issues that cover the main aspects of scientific and technological development, patenting and licensing activities on international and regional scales. Thus, the matters of foreign patenting of domestic inventions and legal protection of intellectual property (G. Androschuk), patenting trends in the world economy and priority areas of patenting in Ukraine (V. Khaustov) have been considered in detail. The works by V. Denysiuk are devoted to the commercialization of research results and international technology transfer. V. Soloviov in his research reveals the financing of scientific research in the context of the development of the knowledge-based economy. National high-tech productions, foreign trade in high-tech goods are the subject of scientific research of O. Salikhova. At the same time, the study of the preconditions for intensifying research work as a catalyst for patenting activities at the national and international levels is becoming relevant. 
Formulation of the purpose of the article. The purpose of the article is to identify the role of human resources in the implementation of patenting activities in terms of the development of the global economy.

Presentation of the main research material. Modern processes of techno-globalism determine the transition to a new paradigm of innovation and technological development. Acceleration of scientific and technological progress has led to radical changes in processes and technology, deepening interaction, interpenetration and convergence of technological systems. The combination of investment and innovation defines the essence and prospects of the technological paradigm, each being associated with the implementation and use of important scientific and technological advances.

According to the researchers, the previous paradigm was centred around the fact that innovations occur in large firms or in a long chain of added value based on the close relationships of participants in the process. However, the new paradigm justifies that production is based on modular science-intensive technologies developed in small and medium enterprises. In the previous paradigm, the main source of knowledge is attributed to the internal divisions of firms, in the new one it is the use of external sources. In this way, innovation becomes an international commodity that can be successfully used by economic entities in other countries.

According to the report of the Organisation for Economic Co-operation and Development (OECD), the transition to new technology paradigms and innovation-intensive economy benefits primarily those groups in society that, unlike others, use more assets and skills. During the development of the information society, there are both rapid and fundamental technological changes [1, p. 9].

One of the main features of the development of industrial property and of digital economy is the leading role of telecommunications companies, which have been at the top of the list of applicants for patents under the international PCT procedure in 2017-2018. Applications from companies such as Ericsson, Huawei Technologies, LG Electronics, Qualcomm Incorporated, Samsung Electronics, ZTE Corporation relate to digital communications and computer technology.

According to the World Intellectual Property Organization, in 2018, the largest number of applications under the PCT procedure was in the field of digital communications, computers, electrical machines, medical equipment. Ukraine ranks 40th in terms of filing applications for inventions under the international procedure, while lagging behind the US leader is about 360 times [2].

Legal protection of intellectual property should be considered as a financial incentive to invest capital in technological development. According to the research by foreign scientists, the external positive effect of innovation, which consists in the value of this intellectual property for consumers and competing manufacturers, is about three times higher than the personal benefit of the inventor. According to other estimates, the average developer receives at least $20 \%$ of the economic effect of innovation, even with sufficient protection of intellectual property rights. The rest is indi- rectly spread throughout the economic system, encouraging other market participants to actively innovate [3, p. 28].

The use of science and technology as key components of economic development is seen as an approach to developing a long-term vision of industrial development in many countries. On the basis of technological forecasting, the process of identification of basic future technologies is aimed at forming the most effective scientific and technical policy and planning its development. At the national level, technological forecasting performs the function of creating a general model of society. World patent rankings confirm the rapid growth of patenting in China and the Republic of Korea. From 1985 to 2017, the number of applications to the Chinese office increased more than 160 times, in the Republic of Korea - almost 20 times, and at the same time to the US office - 5.3, to the European Patent Office -4.5 , in Japan -1.06 times [4].

Globalization and the corresponding technological changes also determine the trends of job creation and directions of the existing labour markets being restructured. The use of the latest digital technologies contributes to the emergence of non-standard forms of work. Most OECD countries have experienced a significant increase in the share of employment in highly skilled industries and a decrease in the share of employment in areas that require a medium level of labour skills [5, p. 9]. Volumes of applications to the European Patent Organization (EPO) show a steadily growing trend (Figure 1).

As we can see, an effective innovation and technology policy has been actively implemented in the European Union over the last decade. There is an increase in spending on research, and the number of employees engaged in research has risen. Consequently, the number of patents filed with the EPO is growing significantly every year. It is interesting to investigate how productive it is to increase the volume of involvement of specialists in the field of research and development. In our article, we have built an econometric model of the dependence of the indicator of the number of patent applications filed with the EPO on the percentage of human resources employed in R\&D in the EU. To build the model, time series of relevant indicators for the period 2010-2019 were used. The linear regression model reflects the relationship between these indicators:

$$
\mathrm{Y}=-67,78+5,2162 * \mathrm{X}
$$

where $\mathrm{Y}$ stands for the number of patent applications,

$\mathrm{X}$ is the share of employees in the field of research and development.

The intensity of the relationship between the variables included in the model is measured by the correlation coefficient. For our model, its value is 0.94 , which indicates that there is a close direct relationship between the variables. The coefficient of determination shows that $88 \%$ of the dependent variable is explained by the influence of the independent variables. Checking the reliability of the regression model and the correlation coefficient based on Fisher's criterion gives reasons to conclude about the adequacy of the model, as the observed value of F-statistics 56.1 is greater than the table value at 0.05 . The independent variables included in 


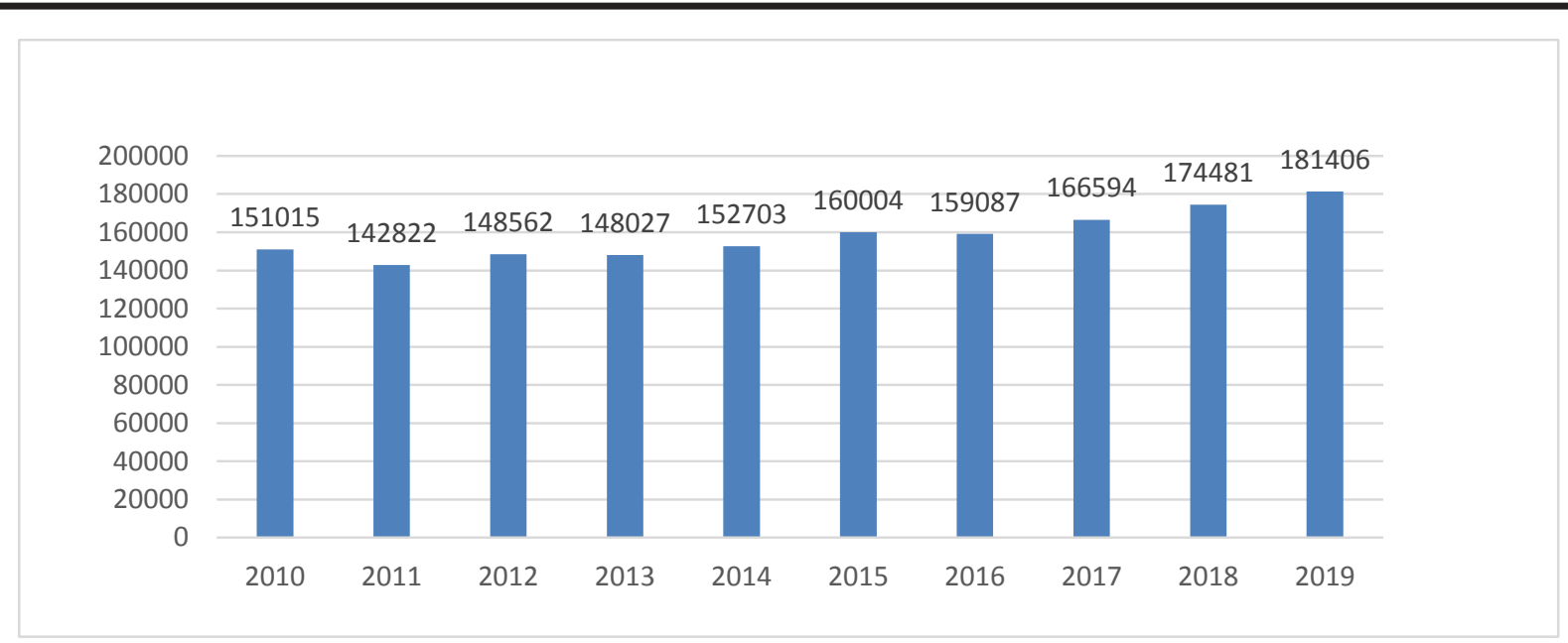

Figure 1. Patent applications filed with the European Patent Organization

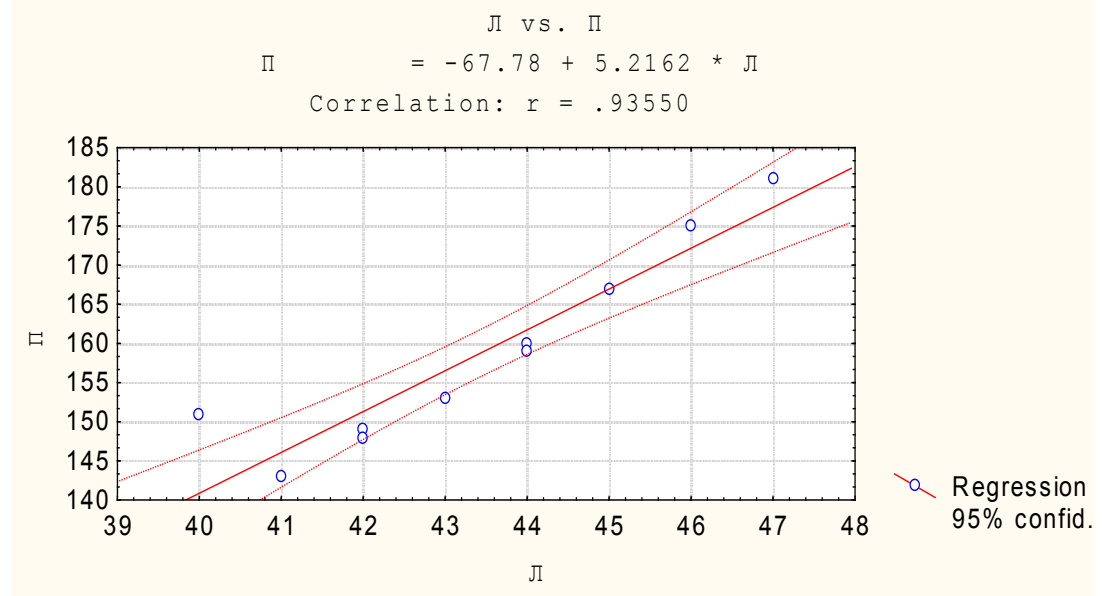

Figure 2. Dependence of the number of patent applications on the share of $R \& D$ employees in the $E U$

the model are statistically significant. The Durbin-Watson statistic recorded the calculated value $\mathrm{DW}=1.14$. When comparing it with critical statistical values (level 0.01, number of factors 1 , number of observations 10) d1 $=0.604$ and $\mathrm{d} 2=1.001$, we can conclude that the hypothesis of no residual autocorrelation is acceptable. Thus, we can say that the growth in the share of employees involved in R\&D by $1 \%$ will increase the number of filed patent applications by 5.2162 thousand. The results of the study prove an important role of human resources in the patenting activities.

In general, the initiators of technology are the economies, where under the pressure of competition there is an update of technology and the introduction of new products. Factors of price and non-price competition force entrepreneurs to move their production to countries where labour costs are lower, and the level of staff skills allows them to master such technologies. These countries, with the growth of technological potential, human resources potential and wages, transfer production capacity to countries that lag behind in technological development., Technologies move from the upper level of the technical and economic pyra- mid to the nearest position, accelerating the pace of development and pulling up to the top of the pyramid [6, p. 40].

The challenges of techno-globalization lead to the introduction in different countries of the concept of technological activity, which aims to maintain competitiveness under the influence of internal and external factors. The countries determine the priorities of innovation, investment and technological development, the areas for improving human capital, financing of scientific and technical developments, etc.

Conclusions. The modern global economy determines the priorities and forecasting of countries' development on the basis of innovation and technology. The indicators of patenting activities determine the prospects for the development of national economies; human resources play an important role in these processes. Post-industrial society stimulates the need to involve highly skilled employees in production processes and forms demands for quality professional training. Given the incomplete compliance of domestic patenting with the global trends, attention should be paid to the formation of public policy to improve human capital, which may be the subject of further research. 


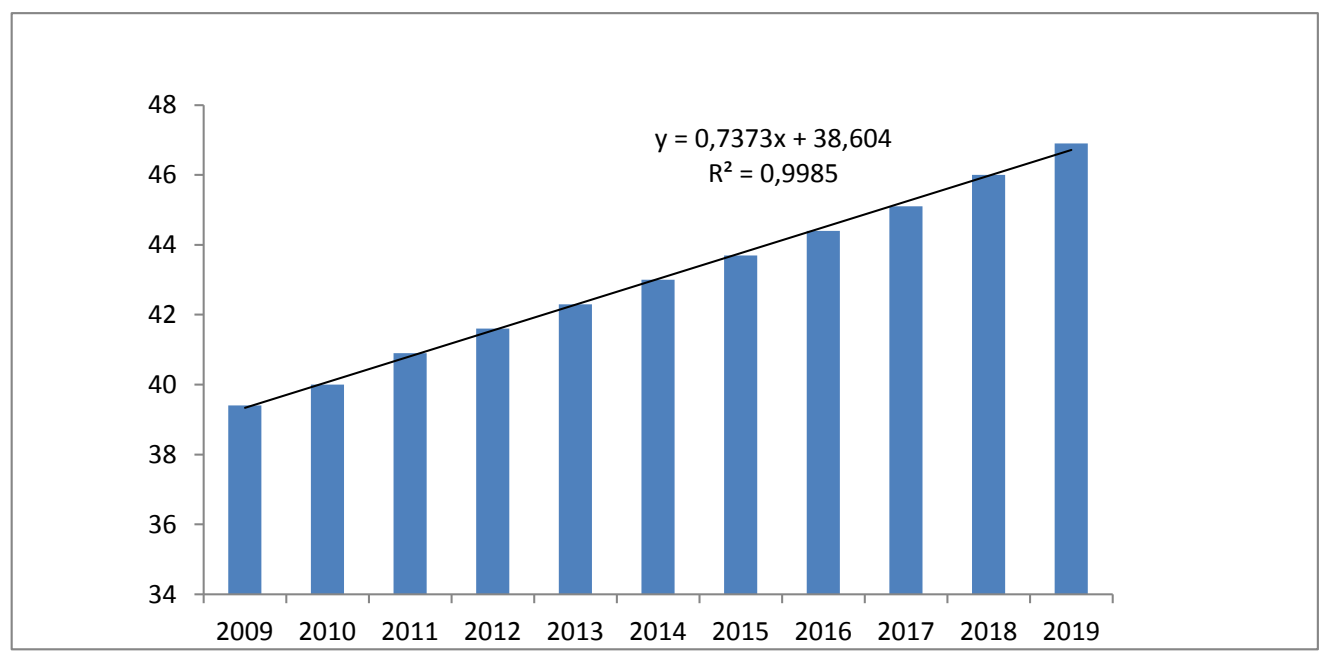

Figure 3. Human resources in science and technology of the EU member states, $\%$

\section{References:}

1. All on Board Making Inclusive Growth Happen. Report by OECD. 2014. Available at: https://www.oecd.org/inclusivegrowth/all-on-board-making-inclusive-growth-happen.pdf (accessed: 17.05.2020).

2. Khaustov V. Tsifrovaia ekonomika: kak tebe sluzhitsia? [Digital Economy: How Do You Serve?]. Available at: https://zn.ua/macrolevel/cifrovaya-ekonomika-kak-tebe-sluzhitsya-333086_html (accessed: 12.06.2020).

3. Sumyn A. V., Kharlamova V. N., Abramova A. V. (2010). Mezhdunarodnaia torgovlia obiektami intellektualnoi sobstvennosti [International Trade of Intellectual Property]. Moskva: Prospekt, 240 p.

4. Khaustov V. Patenty na razvitie. [Development Patents]. Available at: https://zn.ua/macrolevel/patent-narazvitie-325036 .html (accessed: 20.06.2020).

5. The Framework for Policy Action on Inclusive Growth. OECD. Paris, 2018. Available at: https://www.oecd.org/mcm/ documents/C-MIN-2018-5-EN.pdf (accessed: 28.05.2020).

6. Korolev I. (2011). Mirovaia ekonomika: globalnye tendentsyii za 100 let [Global Economy: Global Trends over 100 years]. Moskva: Yurist, 604 p.

\section{Список літератури:}

1. All on board making inclusive growth happen. Report OECD. 2014. URL: https://www.oecd.org/inclusive-growth/allon-board-making-inclusive-growth-happen.pdf (дата звернення: 17.05.2020).

2. Хаустов В. Цифровая экономика: как тебе служится? URL: https://zn.ua/macrolevel/cifrovaya-ekonomika-kaktebe-sluzhitsya-333086_html (дата звернення: 12.06.2020).

3. Сумин А. В., Харламова В. Н., Абрамова А. В. Международная торговля объектами интеллектуальной собственности. М.: Проспект, 2010. 240 с.

4. Хаустов В. Патенты на развитие. URL: https://zn.ua/macrolevel/patent-na-razvitie-325036_html (дата звернення: 20.06.2020).

5. The Framework for Policy Action on Inclusive Growth. OECD, Paris, 2018. URL: https://www.oecd.org/mcm/ documents/C-MIN-2018-5-EN.pdf (дата звернення: 28.05.2020).

6. Королев И. Мировая экономика: глобальные тенденции за 100 лет. М.: Юрист, 2011. 604 с.

\section{ПАТЕНТНАЯ ДЕЯТЕЛЬНОСТЬ И ТЕХНОЛОГИЧЕСКОЕ РАЗВИТИЕ В ГЛОБАЛЬНОЙ ЭКОНОМИКЕ}

Статья посвящена исследованию современных тенденций патентной деятельности в условиях глобальных экономических прочессов. Рассмотрены приоритеты и цели выработки долгосрочного видения развития стран мира в контексте формирования цчифровой экономики. Оиенена роль правовой охраны объектов интеллектуальной собственности в достижении высоких показателей патентования. Приведены компаративные данные мировых рейтингов патентования. Освещены существующие проблемы в отечественном патентовании научно-технических решений. Построено эконометрическую модель зависимости показателя количества патентных заявок, поданных в Европейскую патентную организацию, от показателя проиента человеческих ресурсов, занятых в сфере НИОКР в ЕС. Доказано определяюшую роль в научно-технологическом развитии и патентной деятельности человеческих ресурсов, что требует взвешенной государственной политики в направлении улучшения человеческого капитала.

Ключевые слова: технологии, технологическое развитие, патент, патентная деятельность, глобальная экономика. 


\section{ПАТЕНТНА ДІЯЛЬНІСТЬ ТА ТЕХНОЛОГІЧНИЙ РОЗВИТОК У ГЛОБАЛЬНІЙ ЕКОНОМЦІ}

Стаття присвячена дослідженню тенденцій та пріоритетів технологічного розвитку та патентної діяльності на міжнародному рівні. Актуальність теми обумовлена активізацією конкуренції у сфері патентування провідних технологічно-інноваційних рішень та необхідністю залучення вітчизняних суб' 'ктів господарювання до прочесів світового технологічного обміну. Передумови активізації науково-дослідницької роботи оцінюються як каталізатор патентної активності на національному та міжнародному рівнях. Розглянуто підходи до формування нової сучасної парадчгми технологічного розвитку, при якій виробництво засноване на модульних наукоємних технологіях, які розробляються як великими, так і малими та середніми підприємствами, а джерела знань мають внутрішне та зовнішне походження. У той же час інноваџії стають міжнародним товаром, який ефективно використовується економічними суб 'єктами різних краӥн. Доведено позитивний ефект від нововведення для винахідника, споживачів і виробників-конкурентів. Показано, щзо при формуванні довгострокових програм розвитку багатьох краӥн наука і техніка використовуються як базові складники економічного розвитку. Світові тренди показують стрімке зростання обсягів патентування Китаю та Республіки Корея порівняно з США, СС та Японією. Наголошено на галузевих пріоритетах патентної активності у глобальному вимірі на неповній кількісній та структурній відповідності вітчизняного патентування загальним світовим тенденціям. Враховуючи те, щуо глобалізація та стрімкі технологічні зміни визначають тендениії створення нових робочих місиь, авторами побудована економетрична модель залежності показника кількості патентних заявок, поданих до Свропейської патентної організації, від показника відсотку людських ресурсів, зайнятих у сфері науково-дослідницьких та дослідно-конструкторських робіт у краӥнах-членах ЄС протягом десятирічного періоду. В результаті дослідження доведено вагому роль людських ресурсів у патентній активності, щзо обтрунтовує необхідність розробки нових дієвих підходів до формування державної політики щзодо покращення людського капіталу.

Ключові слова: технології, технологічний розвиток, патент, патентна діяльність, глобальна економіка. 